\title{
STRATIGRAPHIC POSITION OF TILLS IN THE ORŁOWO CLIFF SECTION (NORTHERN POLAND): A NEW APPROACH
}

\author{
Piotr Pawel Woźniak ${ }^{1 *}$, Robert J. Sokołowski², Piotr Czubla ${ }^{3}$, Stanisław Fedorowicz ${ }^{4}$ \\ ${ }^{1}$ University of Gdańsk, Department of Geomorphology and Quaternary Geology, Bażyńskiego 4, 80-309 Gdańsk, Poland, \\ e-mail: geopw@ug.edu.pl \\ ${ }^{2}$ University of Gdańsk, Department of Marine Geology, Pitsudskiego 46,81-378 Gdynia, e-mail: r.sokolowski@ug.gda.pl \\ ${ }^{3}$ University of Łódź, Institute of Earth Science, Narutowicza 88, 90-139 Eódź, Poland, e-mail: piotr.czubla@geo.uni.lodz.pl \\ ${ }^{4}$ University of Gdańsk, Department of Geomorphology and Quaternary Geology, Bażyńskiego 4, 80-309 Gdańsk, Poland, \\ e-mail: geosf@ug.edu.pl \\ * corresponding author
}

\begin{abstract}
The site at Orłowo Cliff was used to analyse the stratigraphic position and palaeogeographic interpretations of the properties and depositional conditions of two basal tills from the Late Pleistocene. A multi-proxy approach involved lithofacies, petrographic analysis of the fine gravel fraction, analyses of indicator erratics and till fabric. TL dating of intra-moraine deposits was used to determine depositional time frames of tills. The sediment profile at Orłowo Cliff shows a distinct reduction in number of Pleistocene units. Obtained dating results suggest the presence of Middle and Late Pleistocene fluvial units. The main issue discussed is the stratigraphic position of the older till (Unit O-4). It can be assumed that this till was deposited probably during the Middle Weichselian (MIS4). At Orłowo Horn the till of Unit O-4 reveals incorporation of the erratic material derived from an older till in the surrounded area (according to petrographic composition - probably from MIS 8). The younger till (Unit O-6) was deposited in the Late Weichselian (MIS 2). Moreover, the till of Unit O-6 is characterised by a significant shift towards the south-west in terms of the erratic origin in Unit O-4.
\end{abstract}

Key words: lithofacies analysis, petrographic composition, till fabric, TL dating, Middle and Late Pleistocene

Manuscript received 13 December 2017, accepted 15 February 2018

\section{INTRODUCTION}

Orłowo Cliff is a unique place on the southern coast of the Baltic Sea where, thanks to modern abrasive processes, Cainozoic sediments of a thickness of several tens of meters (exposed along hundreds of meters) are available for testing (Fig. 1). In the cliff tills are visible which have already been described in a number of publications (including Mojski, 1979a, b; Pępek and Olszak, 1995; Zaleszkiewicz et al., 2000; Bogacka and Rudowski, 2001; Kaulbarsz, 2005). These mostly investigate the issue of the stratigraphic position of glacial sediments, but the results do not, however, settle these issues in a satisfactory manner. Here we present the most recent approach based on a set of dating results, detailed till profiles and the results of their analyses (lithofacies properties, petrographic composition including indicator erratics as well as till fabric). It is the first time that data were collected with a high resolution in till profiles at Orłowo Cliff. The main goals of our work were: (1) to determine the stratigraphic position of till units in Orlowo Cliff, including depositional time frames; (2) correlation of the till layers distinguished - because they do not continue along the whole length of the cliff and the southern and northern parts differ in their geological profiles; (3) discussion of how the analyses applied are effective for the stratigraphic setting; and (4) to use the obtained results for palaeo-geographic reconstructions of the Scandinavian Ice Sheet (SIS) dynamics.

\section{REGIONAL SETTING}

Orłowo Cliff is the eastern, erosional edge of Redłowo Plateau, which is one of the smallest moraine plateaus in the Kashubian Coastland, separated by a system of erosional forms (probably ice marginal valleys; cf. Koutaniemi and 

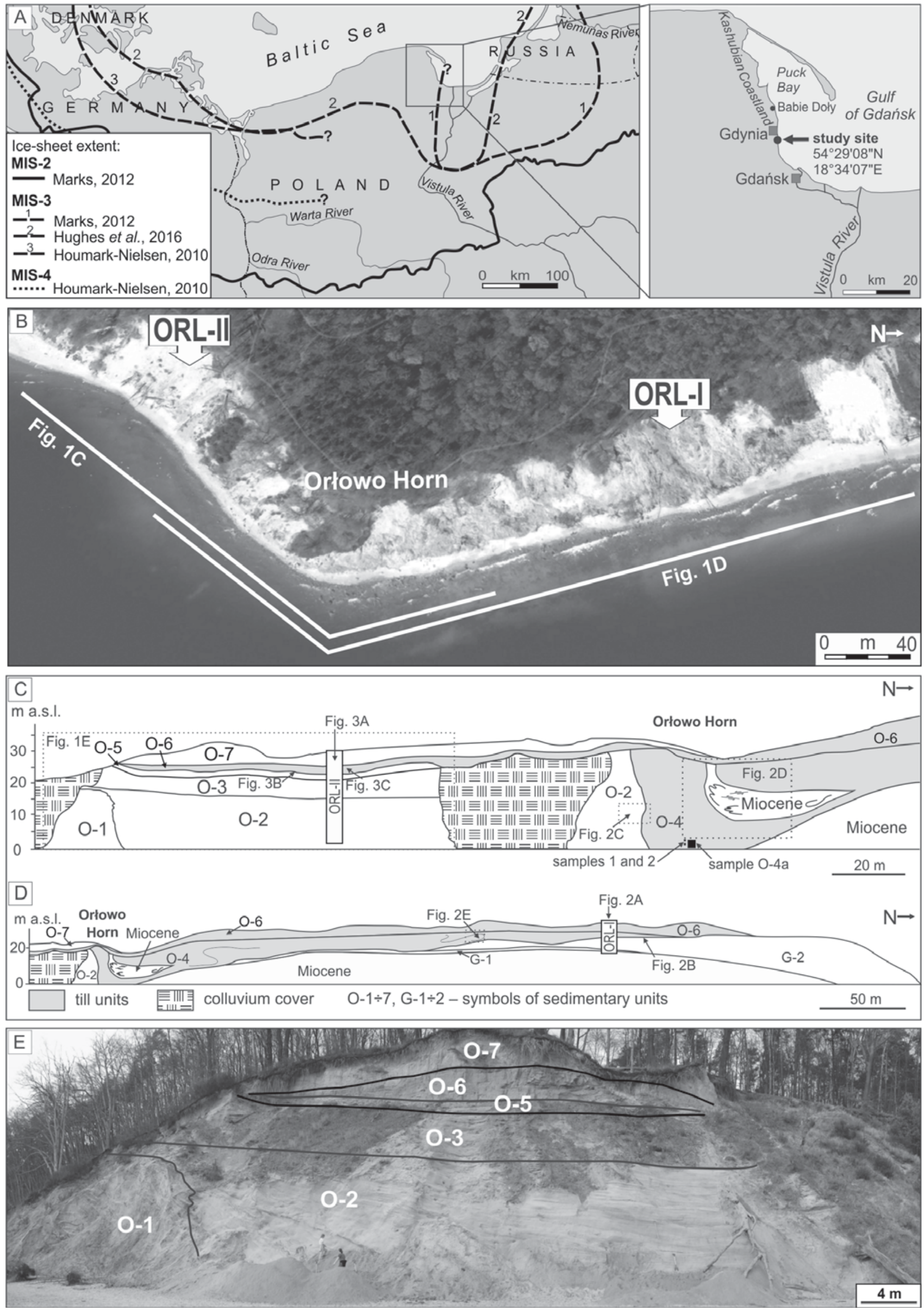
Rachocki, 1987; Kozarski, 1988; Rachocki and Koutaniemi, 1992). Such character of the main topographical features developed during deglaciation of the study area at the end of the last SIS advance ( 15 ka; Marks, 2002, 2012; Mojski, 2005).

The discussed section of the cliff is divided into two parts, northern and southern, separated by Orłowo Horn built of the till of Unit O-4 (Fig. 1C). In both parts of the cliff the intra-moraine deposits (Units O-1, O-2, O-3, O-5, G-1 and G-2; Fig. 1C-D) show different lithology and origins and have no direct contact with each other to allow an unambiguous correlation (Sokołowski, 2014). Therefore, separate classifications were applied to the southern and northern parts of the cliff (Fig. 1C-D). However, for the two levels of delimited till units a consistent system was used (Units O-4 and O-6).

The Pleistocene series in Redłowo Plateau are underlain by Miocene sediments (sands and silts with lignite inserts; cf. Kramarska, 2006, Sokołowski, 2014; Woźniak and Czubla, 2014). Despite the location of the study area within virtually all the SIS transgressions in the Pleistocene, the sediment profile shows a distinct reduction in number of members and their thickness - total thickness is $12-30 \mathrm{~m}$ (Fig. 1C). The Pleistocene sub-till sediments in the southern part of Orłowo Cliff have so far been recognised as a single unit. Mojski (1979a), followed by other authors, considers these deposits as generated in the fluvioglacial environment during the Świecie Stadial (MIS 4) (cf. Zaleszkiewicz et al., 2000; Kaulbarsz, 2005). A new proposition was made by Sokołowski (2014) who delimited three informal lithostratigraphic units in the southern part of Orłowo Cliff. The lowest of these, Unit O-1 (Fig. 1C, E), is consisted of variously-grained deposits. Synsedimentary deformations occurring in the sediments of Unit O-1 indicate flows of hydrated material towards the north-west. Sedimentation took place mainly under sub-aerial conditions creating a fan, presumably of a glacio-marginal type. The two fluvial series above are separated by a distinct erosional boundary (Sokołowski et al., 2010; Sokołowski, 2013). The lower series (Unit O-2; Fig. 1C, E) is composed of sandy sediments from the channel zone of a meandering river. Upwards they transit into a silty-sand rhythmite from the overbank zone. Deposits of Unit O-2 directly underlie the O-4 till in Orłowo Horn (Fig. 1C-D). The top series (Unit O-3) are gravelly-sand deposits of a deep channel braided river. In the case of both fluvial series the measured palaeo-current directions indicate eastbound transport (Sokołowski, 2014). According to our research, Unit O-5 between the fluvial series of Unit O-3 and the till of Unit O-6 should be distinguished. It is composed of the braided river gravelly-sand deposits. Its top part is deformed, as well as probably eroded, by the ice deposited the till of Unit O-6.

In the northern part (the longer section) the Miocene sediments are overlain by a gravelly-cobble unit (G-1) of a thickness of 0.5 to $7 \mathrm{~m}$ (Fig. 1D). Its contact with the underlying Miocene sediments is erosional. The gravelly sediments represent through cross-bedding of a large scale, while the cobble deposits have a clast-supported massive structure with sandy clasts and single over-sized cobbles of a diameter significantly larger than the deposits in which they are embedded. Above is Unit G-2 with a thickness from a few to more than $25 \mathrm{~m}$ (Sokołowski, 2014). These are sands with through cross-bedding on a medium and small scale with some silt inserts. They are overlain by sands of ripple cross-lamination, transitioning into silts with wavy and flaser lamination. The deposits of Unit G-2 were deposited in the channel zone of a sand-bed braided river in periglacial climate conditions (Sokołowski, 2014).

The till levels delimited within the Pleistocene sediments visible in Orłowo Cliff vary from two or three (Mojski, 1979b; Zaleszkiewicz et al., 2000) to five (Kaulbarsz, 2005; Rudowski and Łęczyński, 2009). In addition the stratigraphic position of these till units varies. At Orłowo Horn some authors distinguish two till levels, which - according to these authors - are overthrust and are supposed to have originated during the Saalian Glaciation (Bogacka and Rudowski, 2001; Kaulbarsz, 2005). In the southern part of Orłowo Cliff, Kaulbarsz (2005) describes a till block within the deformed sandy-mud sediments (Unit O-1, Fig. 1D), which she correlates with the Late Saalian Glaciation (MIS 6a). In the top part of the cliff the same author delimits one till in the southern part and two tills in the northern. She correlates them with the Świecie Stadial (MIS 4) and the main stadial of the last glaciation (MIS 2). In contrast, Lisicki (2003) believes that among the tills occurring at the top of the cliff, the younger one belongs to the Main Stadial of the Weichselian Glaciation (MIS 2), and the lower-lying older till - to the Krzna Glaciation (MIS 8, according to Lindner et al., 2013). Lisicki correlates the till forming Orłowo Horn with the Nida Glaciation (MIS 22). It should be emphasised that the cited interpretations are largely based on the results of petrographic analyses of individual samples of the 5-10 mm fraction, and sometimes - on TL dating of till (Pępek and Olszak, 1995; Zaleszkiewicz et al., 2000).

\section{METHODS}

The research was carried out on natural outcrops only situated in three sections of Orłowo Cliff (nature reserve). Lithofacies description was made according to Miall (1978) and Eyles et al. (1983). The samples of the fine-gravel fraction $(5-10 \mathrm{~mm})$ were collected from glacial deposits in all sections (Fig. 2). They were used for examination of the vertical petrographic differentiation of the tills. The authors

$\leftarrow$ Fig. 1. Location maps and sections. A - Location of the study area with lines of maximum ice-sheet extent during the Middle and Late Weichselian in northern Poland and surrounding areas; ice-sheet extent during the Saale Glaciation is further to the south, beyond the map; B - Location of the analysed sections on the Google Earth view; C, D - Geological structure of the southern (C) and northern (D) sections of Orłowo Cliff; location of sample places not presented at logs in Figs. 2A and 3A and the places in photos (Figs. 2B-E, 3B, C) included; E - Southern part of the Orłowo Cliff section. Notice the amalgamated fluvial and fluvioglacial units $(\mathrm{O}-2, \mathrm{O}-3$ and $\mathrm{O}-5)$. 


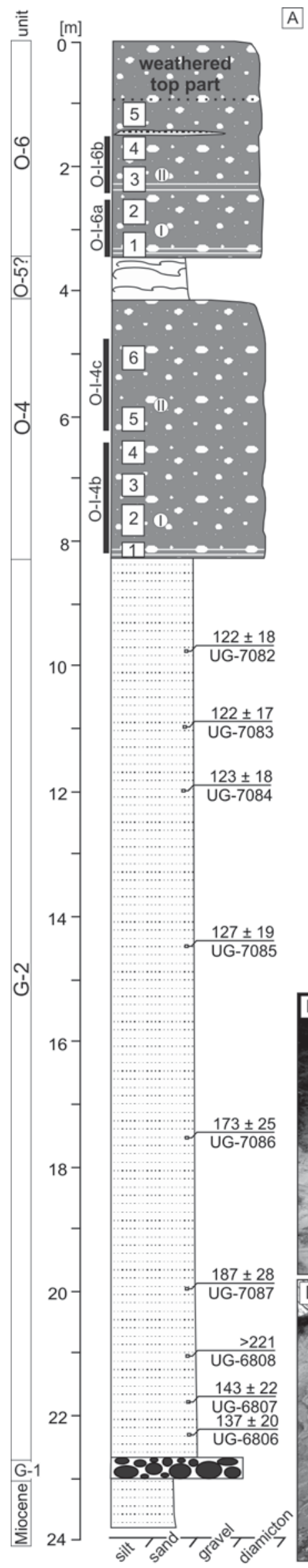

A
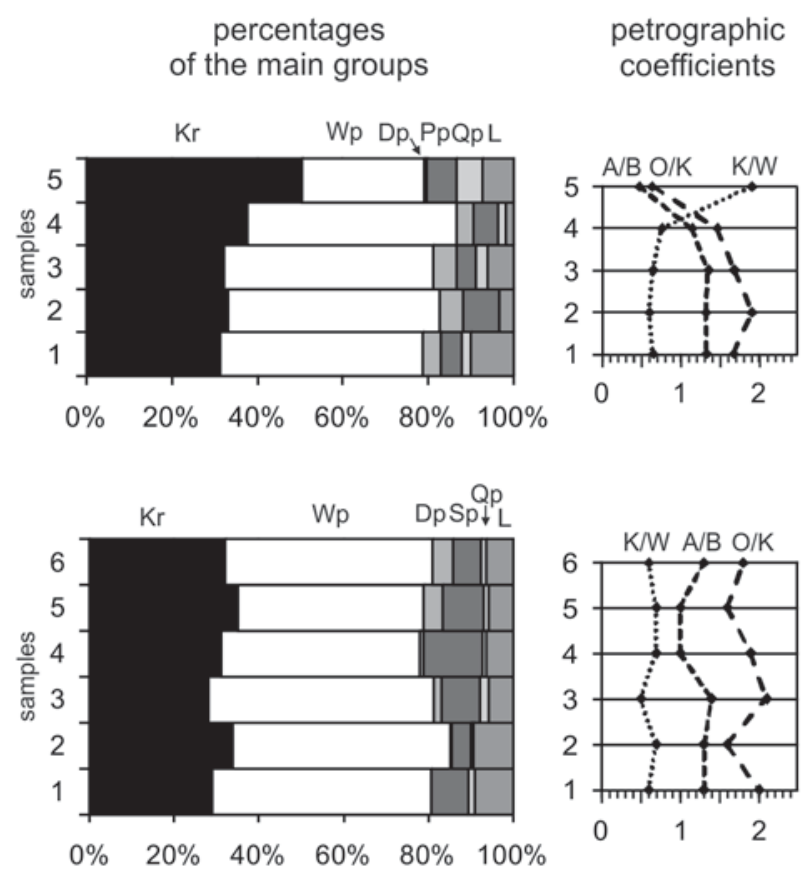

petrographic coefficients
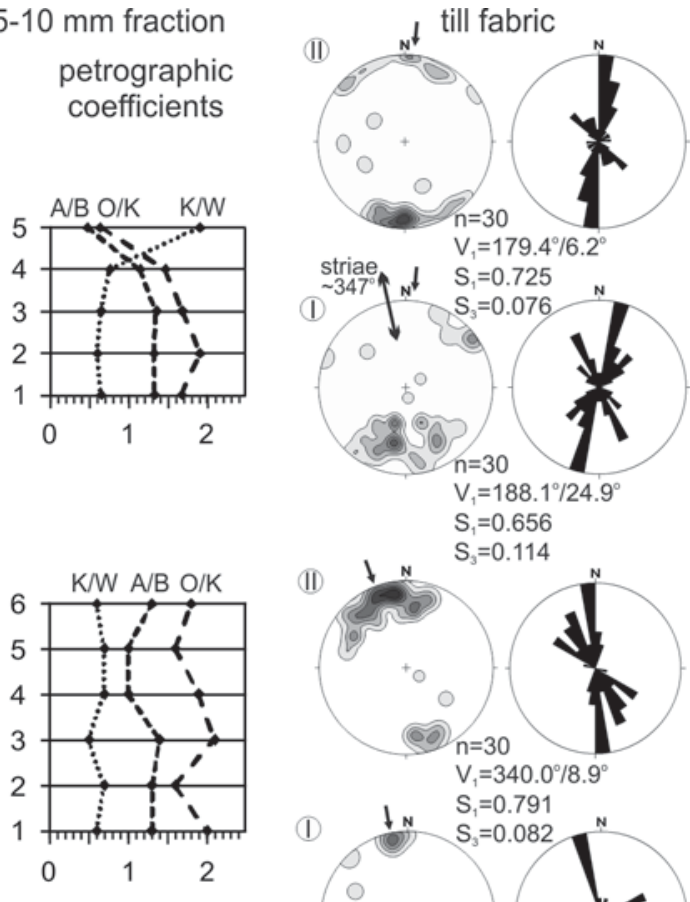

striae $\quad S_{1}=0.725$
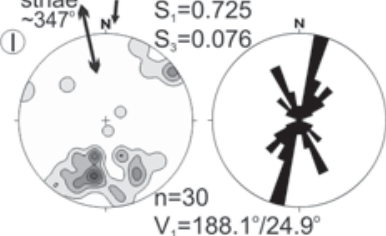

$S_{1}=0.656$

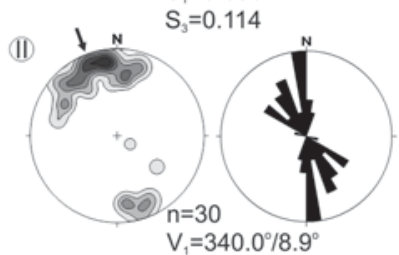

$V_{1}=340.0^{\circ} / 8.9^{\circ}$

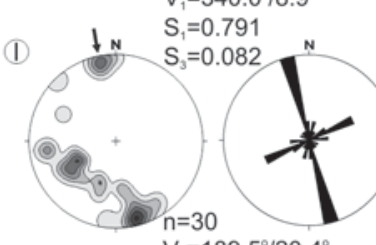

$V=189.5^{\circ} / 20.4^{\circ}$

$\mathrm{S}_{1}=0.614$

The lower part of the till O-4 at Orłowo Horn (sample sites - Fig. 1C) $\mathrm{S}_{3}=0.031$
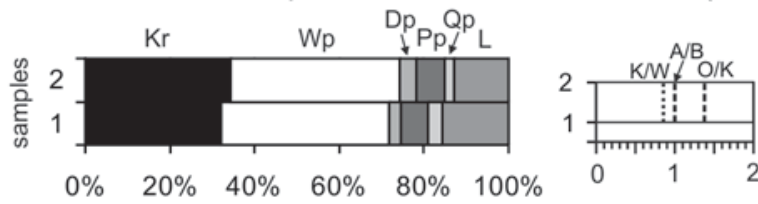

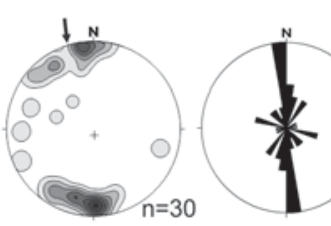

$V=174.7^{\circ} / 0.5^{\circ}$

$S_{1}=0.708$

$\mathrm{S}_{3}=0.040$
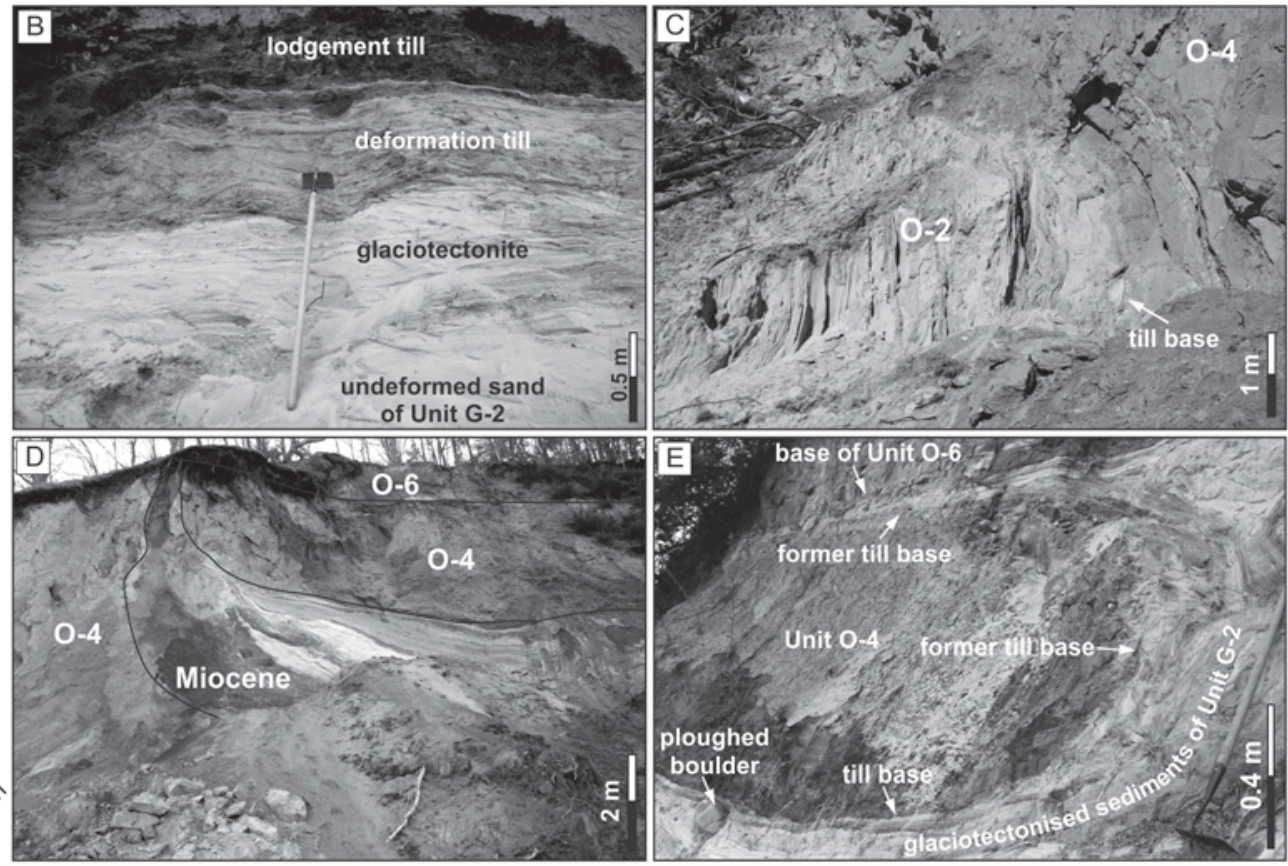
employed the analytic method proposed by Trembaczowski (1961), with later modifications by Rzechowski (1971). The samples were usually collected from $30 \mathrm{~cm}$ sections; but in the base parts just $20 \mathrm{~cm}$ (one metre in the original method). For a detailed description of the method used see Woźniak and Czubla (2016). Moreover, explanations for petrographic-group symbols and petrographic coefficients are placed in Fig. 3. In addition, the matrix $\mathrm{CaCO}_{3}$ content was determined for each sample. Scheibler's volumetric method (also called Chittick's gasometric method, see Dreimanis, 1962) for the $<0.1 \mathrm{~mm}$ fraction was applied. It enabled the determination of decalcification variability within the vertical profile and excluded from petrographic analyses the decalcified part of the till.

The facies characteristics of the till body, and vertical petrographic differentiation of the 5-10 $\mathrm{mm}$ fraction, were used to divide the investigated till unit into subunits. For each subunit, independent petrographic composition analyses of medium and coarse gravels and till fabric measurements were made. Typically, each set selected for examination of till fabric contained at least 30 pebbles of considerable elongation (length ratio of the pebble axes, $a / b$, at least 1.5/1) with the a-axis length between 2 and $10 \mathrm{~cm}$. Orientation of striae on the top surfaces of large pebbles in the base of the till was also determined. For petrographic composition analyses of medium and coarse gravel samples, clasts from the fraction of $>20 \mathrm{~mm}$ (no upper limit) were collected. All the necessary calculations, including theoretical boulder centre (TBC) coordinates, were made employing the method by Lüttig (1958), as modified by Smed (1993), Vinx et al. (1997) and Czubla (2001).

To determine the age of sub- and over-till sediments TL method was used. The samples were collected using metal tubes (50 cm in length, $5 \mathrm{~cm}$ in diameter) hammered into the sediment. The TL dating was performed in the laboratory of the Department of Geomorphology and Quaternary Geology, University of Gdańsk. The multiple-aliquot regenerative technique (Wintle and Prószyńska, 1983) on quartz grains $(63-90 \mu \mathrm{m})$ was used. For a detailed description of the dating process see Fedorowicz et al. (2013).

\section{DESCRIPTION AND INTERPRETATION OF THE FEATURES OF ANALYSED TILLS}

\section{Unit 0-4}

\section{Facies characteristics}

Till of Unit O-4 has a variable thickness, ranging from at least $12-15 \mathrm{~m}$ in the area of Orłowo Horn, until its gradual disappearance in the northern part of the cliff and its absence to the south (Fig. 1C-D). Only its thin base part (up to $5 \mathrm{~cm}$ ) reveals a stratified nature, while almost the whole profile is composed of massive diamicton (Fig. 2A), The contact of the till with the substrate mostly shows a deformational character. Sub-till sediments are glaciotectonised (zone of thickness up to $1.5 \mathrm{~m}$ ) and between their top and the lodgement till a zone of deformation till occurs (Fig. 2B). More spectacular deformations are especially visible at Orłowo Horn. In its southern part, at the contact with sediments of Unit O-2, there are deformations in the form of fine drag folds and secondary laminations of the deposit (Fig. 2C). In the northern part of Orłowo Horn an ice raft of sandy-silty-loam sediments was documented within the till (Fig. 2D). The ice raft (at least 15-20 $\mathrm{m}$ long and about $8 \mathrm{~m}$ thick) forms an elongated lens of Miocene deposits inclined toward the north. Unit O-4 is deformed not only at Orłowo Horn, but in the northern part of Orłowo Cliff disruption and overthrusting was documented (Fig. 2E). Because of a thick colluvial cover and the limited scope of work permitted in the reserve it is hard to trace whether there are other such deformations.

\section{Petrographic composition of the 5-10 $\mathrm{mm}$ fraction}

Six samples were collected from the till profile of Unit O-4 (Fig. 2A) to study the petrographic composition of the fine-gravel fraction. Control of the $\mathrm{CaCO}_{3}$ content in the matrix showed that it varies slightly (from $8.0 \%$ to $9.5 \%$ ) in the profile studied. This indicates no decalcification of the till, thereby preserving its original petrographic composition.

In the entire profile sedimentary rocks predominate over crystalline (high coefficient $\mathrm{O} / \mathrm{K}$ and low $\mathrm{K} / \mathrm{W}$; Fig. 2A; for explanations for petrographic-group symbols see Fig. 3). This is mainly due to a very high content of Palaeozoic limestones; in the three lower samples they represent over half of all the gravels, slightly less in the top. The profile diversity is mainly influenced by Palaeozoic dolomites (Dp), Proterozoic and Palaeozoic sandstones $(\mathrm{Pp})$, and rocks of local provenance $(\mathrm{L})$. The quantity of dolomites is very low in the first of the four lowermost samples, while in the samples from the top it abruptly increases, even fourfold. The quantity of sandstones varies differently: first its proportion increases significantly in an upward direction, then in the topmost samples it clearly decreases. The largest share of rocks of local provenance is observed in the bottom part ( $\sim 9 \%$, including individual pieces of Miocene lignite), in the upper parts their percentage has diminished to $6 \%$. In the light of the results, the till profile analysed was divided into two parts (different quantities of Palaeozoic dolomites and sandstones and rocks of local provenance) in which further research was undertaken separately: analyses of the petrographic composition of the $>20 \mathrm{~mm}$ fraction and the till fabric.

At Orłowo Horn, because of restrictions in a protected area, it was impossible to analyse the whole till profile. Only two samples were collected. Their petrographic com-

$\leftarrow$ Fig. 2. Overview of the results in ORL-I section and selected features of Unit O-4. A - Log of the ORL-I section and results of selected analyses; for explanation see Fig. 3; B - Deformation zones at the contact of till O-4 with the sediments of Unit G-2; C - Overthrust at Orłowo Horn; D - Block of Miocene deposits in the till O-4 at Orłowo Horn; E - Deformed till O-4 (disrupted and overthrusted). 


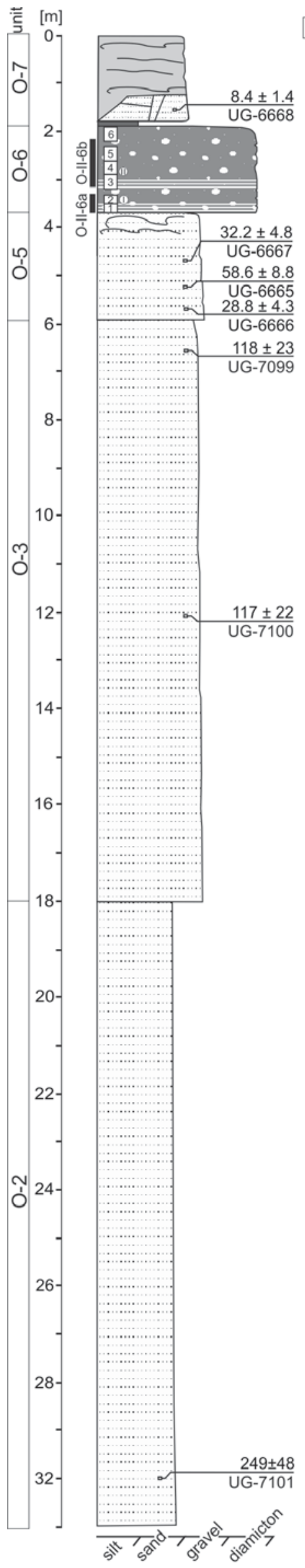

A

petrographic composition of the $5-10 \mathrm{~mm}$ fraction
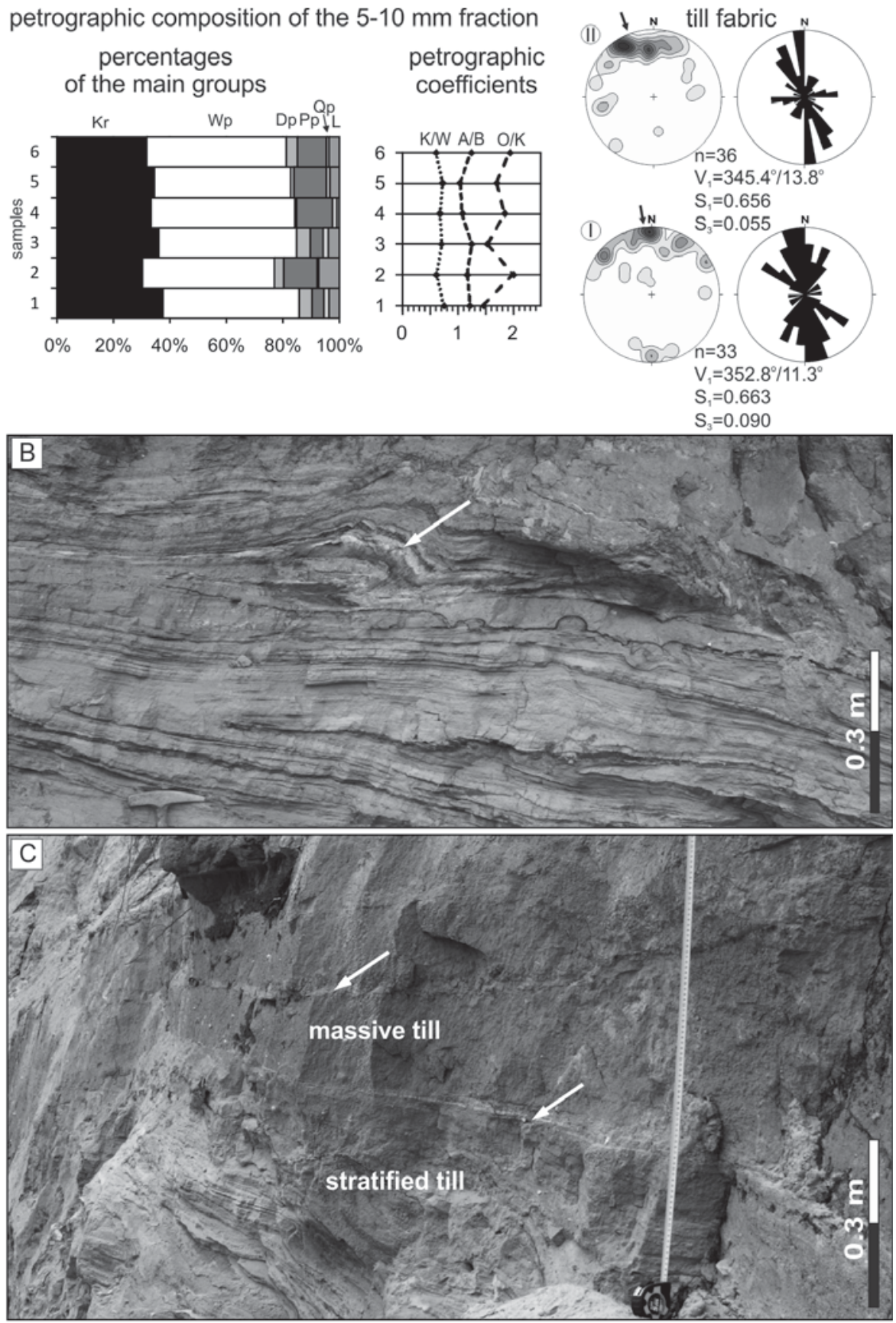

Lithology

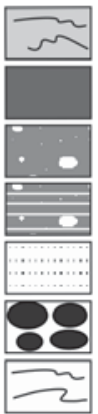

diamictic gravity-flow deposits

glaciolacustrine silt

massive till

stratified till

fluvial / fluvioglacial sands and gravels

fluvioglacial coarse gravels

deformed sediments

\section{Symbols}

$\sim$ samples for TL dating: age in ka and laboratory number

samples for petrographic analyses of fraction $>20 \mathrm{~mm}$; see Figs. 4 and 5

$\square$ samples for petrographic analyses of fraction 5-10 mm

till fabric measurements $\mathrm{n}$ - sample size

$V_{1}$ - eigenvector: azimuth/dip (azimuth is marked by an arrow) $\mathrm{S}_{1}, \mathrm{~S}_{3}$ - eigenvalues

\section{Petrographic composition}

$\mathrm{Kr}$ - Proterozoic crystalline (igneous and metamorphic) rocks; Wp - Palaeozoic limestones; $\mathrm{Dp}$ - dolomites; $\mathrm{Pp}$ - Proterozoic and Palaeozoic sandstones and quartzites;

$\mathrm{Qp}$ - quartz originating from disintegrated crystalline rocks; $\mathrm{L}$ - rocks of local provenance $\mathrm{O} / \mathrm{K}=(\mathrm{Wp}+\mathrm{Dp}+\mathrm{Pp}+\mathrm{Lp}) /(\mathrm{Kr}+\mathrm{Qp}) ; \mathrm{K} / \mathrm{W}=(\mathrm{Kr}+\mathrm{Qp}) /(\mathrm{Wp}+\mathrm{Dp}) ;$

$\mathrm{A} / \mathrm{B}=(\mathrm{Wp}+\mathrm{Dp}) /(\mathrm{Kr}+\mathrm{Pp}+\mathrm{Qp})$ 
positions were very similar. Mutual predominance of sedimentary over crystalline rocks is noted $(\mathrm{O} / \mathrm{K}=1.37)$. What is more, the share of rocks of local provenance is close to $15 \%$, (including gaizes and cherts).

\section{Petrographic composition of the $>20 \mathrm{~mm}$ fraction}

In both samples collected from section ORL-I (Fig. 2A) there are few rocks of the local provenance - less than $0.5 \%$. Among Baltic-Fennoscandian rocks there is a significant predominance of sedimentary rocks. Crystalline rocks represent only about $30 \%$ (28.9\% in the lower sample and $33.0 \%$ in the upper one) of this group while sedimentary rocks are most strongly represented by Palaeozoic limestones and dolomites: $55.7 \%$ and $8.4 \%$ respectively in the lower, and $52.5 \%$ and $7.2 \%$ in the upper part of the till unit. Dolomites are present in a greater quantity than sandstones resistant to weathering (approximately $7 \%$ in both samples).

A high proportion of calcareous rocks, including dolomites and Wesenberg limestone derived from the eastern part of the Baltic Sea Basin, with a modest share of red Ordovician limestones and a small quantity of sandstones that occur mainly in the western part of the Baltic Sea Basin and on the Swedish mainland (cf. Fredén, 1994; Smed, 2002; Śliaupa and Hoth, 2011), indicates the dominance of the eastern part of Fennoscandia and the Baltic Sea Basin as source areas of debris transported by ice. Similar conclusions can be drawn from an analysis of crystalline indicator erratics, which completely lack rocks from Bornholm and Skåne, while Småland erratics are represented in small quantities (Fig. 4B-C, nos. 20, 21). The prevailing material is derived from Uppland and the regions of Åland and Dalarna - respectively $27.3 \%, 24.2 \%$ and $27.3 \%$ in the lower sample, and $37.8 \%, 29.7 \%$ and $16.2 \%$ in the upper. The importance of the eastern and northern debris source areas is documented in the circle maps (Fig. 4B-C, nos. 1, $3,4,10-15,17,18$ and 27), as well as the theoretical boulder centres (TBC) located in the far north-eastern part of the diagram (Fig. 5 : $17.2^{\circ} \mathrm{E}, 60.0^{\circ} \mathrm{N}$ for the lower part, and $17.4^{\circ} \mathrm{E}, 59.6^{\circ} \mathrm{N}$ for the upper part of the till bed).

In the sample from Orłowo Horn (sample O-4a; see Fig. 1C), local rocks (including flint and cherts) occur in small quantities - only $1.2 \%$ of the sample. Among Fennoscandian erratics there are many carbonate rocks, accounting for almost $60 \%$. The proportion of dolomites $(5.3 \%)$ is lower than in O-4 till from the ORL-I section $(8.4 \%)$, but the content of eastern Baltic limestone is only slightly higher (11.7\% of Fennoscandian carbonate erratics) compared to $9.1 \%$ in the lower till. The proportion of sandstones is also similar (8.6\% versus $6.9 \%)$. Crystalline rocks constitute about $31.5 \%$ of Fennoscandian erratics. Among the identified crystalline indicator erratics (46 clasts), those from Dalarna (28.3\%) predominate, while quantities from
Åland and Uppland are slightly lower but even (23.9\%, Fig. 4C). The theoretical boulder centre (calculated basing on crystalline erratics only) has the coordinates $16.7^{\circ} \mathrm{E}$, $59.6^{\circ} \mathrm{N}$ (Fig. 5).

\section{Till fabric}

Three measurement sets of till fabric were made: two in the same places where the $>20 \mathrm{~mm}$ fraction was sampled, i.e. in the analysed profile, while the last one was outside the ORL-II section in the lower part of the till making up Orłowo Horn. All of them point to an ice sheet advance from the NNW sector. It should be noted, however, that some of the measurement sets display a specific direction distribution (Fig. 2A), with bimodal or even polymodal being observed, while at the same time the concentration of results is relatively large (low isotropy), which is indicated by the eigenvalues $S_{1}$ and $S_{3}$. A large number of clasts show a down-glacier tilt (only in set no. II does the azimuth of the eigenvector $\mathrm{V}_{1}=340^{\circ}$ directly indicate the NNW sector), which is the main cause of bimodal direction distribution. The most consistent is the distribution of directions in the bottom of the till making up the core of Orłowo Horn, although here down-glacier tilted pebbles predominate $\left(\mathrm{V}_{1}=174.4^{\circ}\right)$. It is worth noting that in the horn a joint system (also observed in the analysed till in other parts of the cliff) is best expressed whose strike is arranged roughly along the W-E axis.

\section{Interpretation}

Interpretation of directional characteristics, not only understood as till fabric but also resulting from the petrographic composition, requires looking at this issue at different scales (from local to supra-regional). The till fabric characteristics mainly give information about local directions. All the series suggest the ice sheet advanced from the NNW, even though, as mentioned, some have a specific distribution. Heterogeneity of distribution can be associated with the formation of shear systems (series no. II in Fig. 2A) and rotation of clasts (series no. I) which followed the deposition of moraine material while overcoming morphological barriers in the form of pre-existing plateau areas. When the clasts were subjected to high stress, the orientation of their rotation changed from parallel (Jeffrey rotation) to transverse (Taylor rotation) in relation to the ice movement (see Carr and Rose, 2003). It is possible that one of the causes of the specific orientation distributions of the clasts might have been the post-depositional rotation of the bed (a distinct tilt of the till bed was observed).

Analysis of the composition of the gravel fraction and indicator erratics in till O-4 in Orłowo proves it was deposited by the ice sheet supplied with material from the region of the Åland Islands and the north-eastern part of the Baltic

$\leftarrow$ Fig. 3. Overview of the results in ORL-II section and selected features of Unit O-6. A - Log of the ORL-II section and results of selected analyses; B - Stratified diamicton with sandy-gravelly laminae of the deposits of Unit O-5 incorporated in the bottom of the Unit O-6; the arrow indicates a strongly stretched body of Miocene deposits; C - Stratified and massive till of Unit O-6; arrows indicate sandy intercalations. 


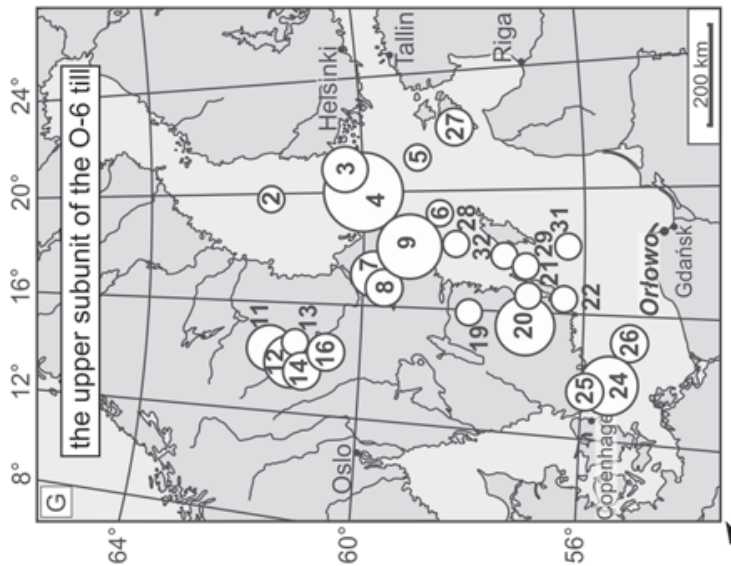

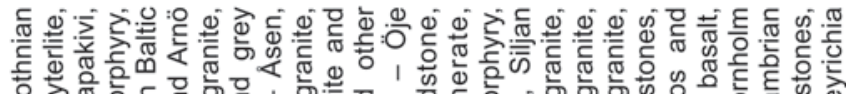

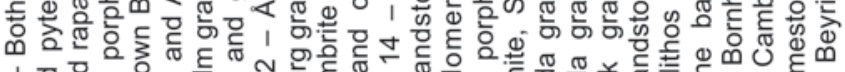

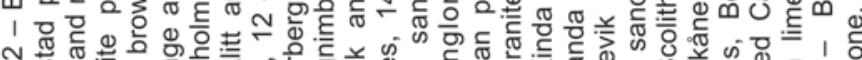

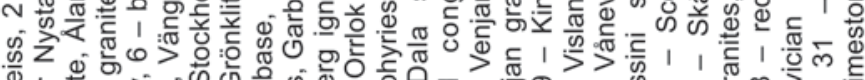
is ๘ ᄃ

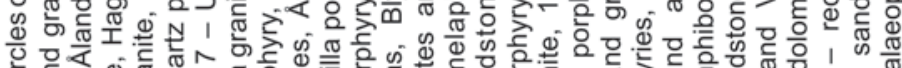

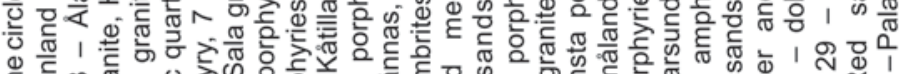

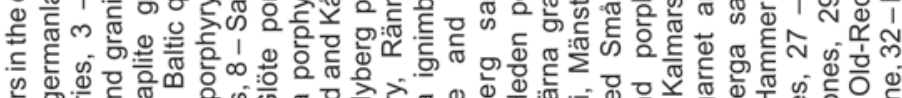

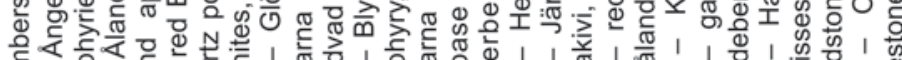

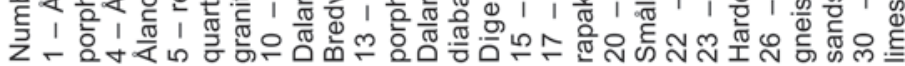
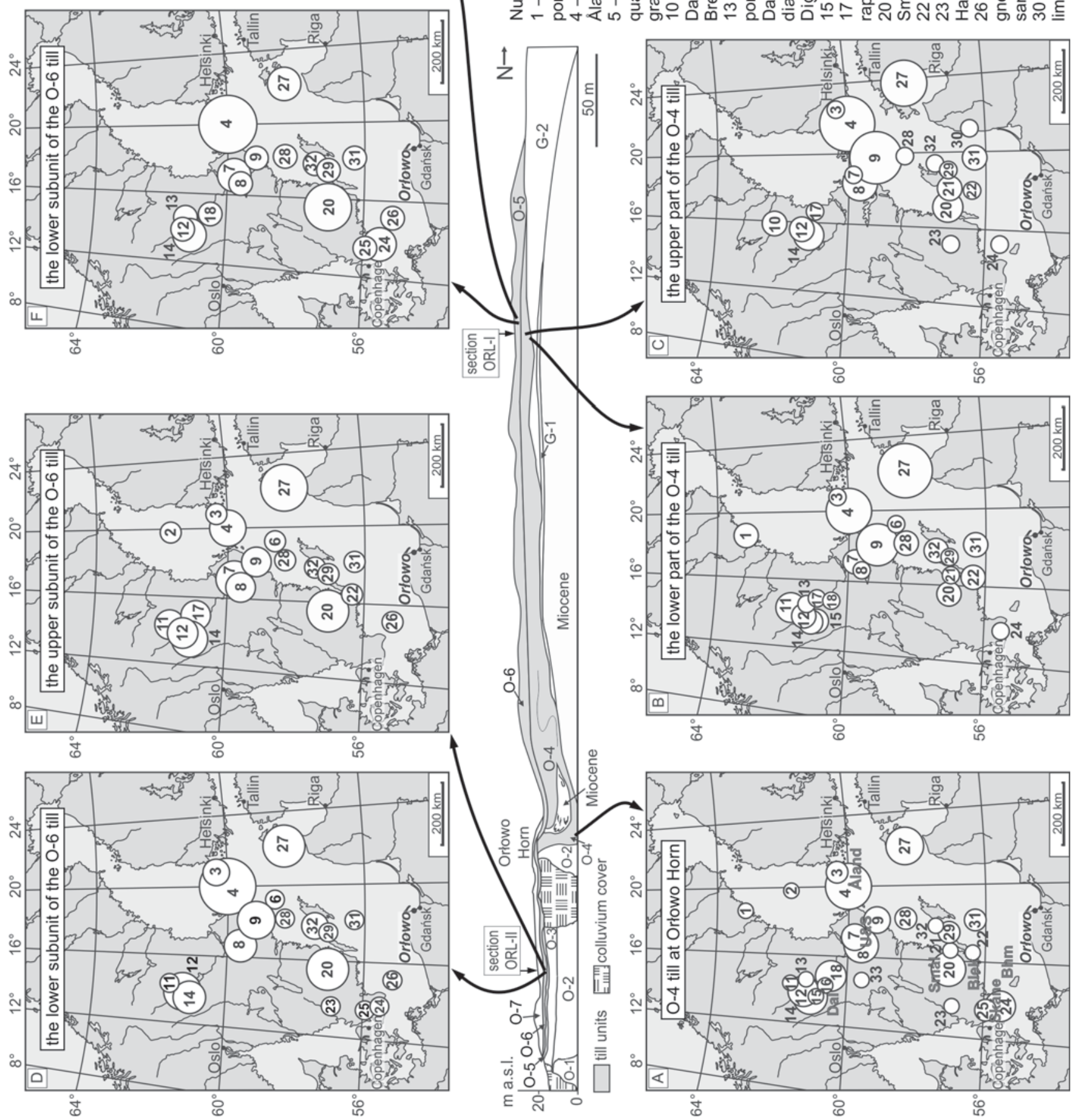
Sea Basin. The sample from Orłowo Horn (O-4a) contains more Dalarna erratics (Fig. 4A) than both samples collected from O-4 till in the ORL-I section (samples O-I-4b and O-I-4-c; Fig. 4B-C). It is interesting that the contribution of the Dalarna rocks in the till exposed at Orłowo Horn is only slightly higher than in the lower sample from the ORL-I section (O-I-4b). Only the upper part of Unit O-4 till in that section (sample O-I-4c) is heavily impoverished (poorer) in erratics from this region. The enrichment in Dalarna rocks in the lower subunit of O-4 till in the northern part of Orłowo Cliff and in Orłowo Horn could be explained by incorporation of gravel fraction from older Pleistocene deposits (containing many erratics from Middle Sweden) by advancing ice sheet. It cannot be excluded too that the change in petrographic composition within Unit O-4 occurred as a results of the migration of the glaciation centre to the east in the course of a single glaciation according to Ehlers' concept (Ehlers, 1981, 1983; Ehlers and Stephan, 1983). This would mean that Unit O-4 till was squeezed at Orłowo Horn and its upper part (poorer in Dalarna rocks) making up the upper part of cliff face is not available for sampling.

\section{Unit O-6}

\section{Facies characteristics}

Unit O-6 is a brown sandy till of variable thickness (Fig. 1C-D). It continues along almost the entirety of Orłowo Cliff and only broken by minor erosive incisions. In the northern part of the cliff it lies directly on Unit O-4 till, or on Unit G-2 sediments (Fig. 1D). At places it is separated from Unit O-4 till by deformed sandy sediments of a thickness of up to one metre (Fig. 2A, E). The till described is associated with the deformation of underlying sediments, most commonly asymmetric folds (Fig. 3B).

Unit O-6 till reaches a thickness of 5-6 m (locally up to $8 \mathrm{~m}$ ) in the northern part of the cliff. In the southern part this thickness decreases, typically to not more than $2 \mathrm{~m}$ (Fig. 1C) and, in the southernmost section, it decreases to only $40 \mathrm{~cm}$ (no signs of their top erosion). The base part of the till (from a few to approx. $20 \mathrm{~cm}$ ) is stratified diamicton (laminae of up to several $\mathrm{mm}$ ) with very thin laminae of sand or gravel (Fig. 3B, C). At the base there are occasional boulders with ploughing marks. In the upper parts the diamicton reveals a massive structure (Fig. 3C). The situation described for the lower part (stratified diamicton followed by massive diamicton) is repeated in the middle of the bed. Within the diamicton there are also small

$\leftarrow$ Fig. 4. Indicator erratics in the analysed tills; Unit O-4: A - sample O4-a (Orłowo Horn), B - sample O-I-4b, C - sample O-I-4c; Unit O-6: D - sample O-II-6a, E - sample O-II-6b, F - sample O-I-6a, G - sample O-I-6b; sampling sites - see Figs. 1C, 2A and 3A; source areas of indicator erratics mentioned in the text (bold grey letters in Fig. 4A): Åland - Åland region, Bhm - Bornholm, Blek - Blekinge, Dal - Dalarna, Skåne - Skåne, Smål Småland, U\&S - Uppland and Stockholm region; circle area corresponds with the percentage of erratics in the analysed stone sample.

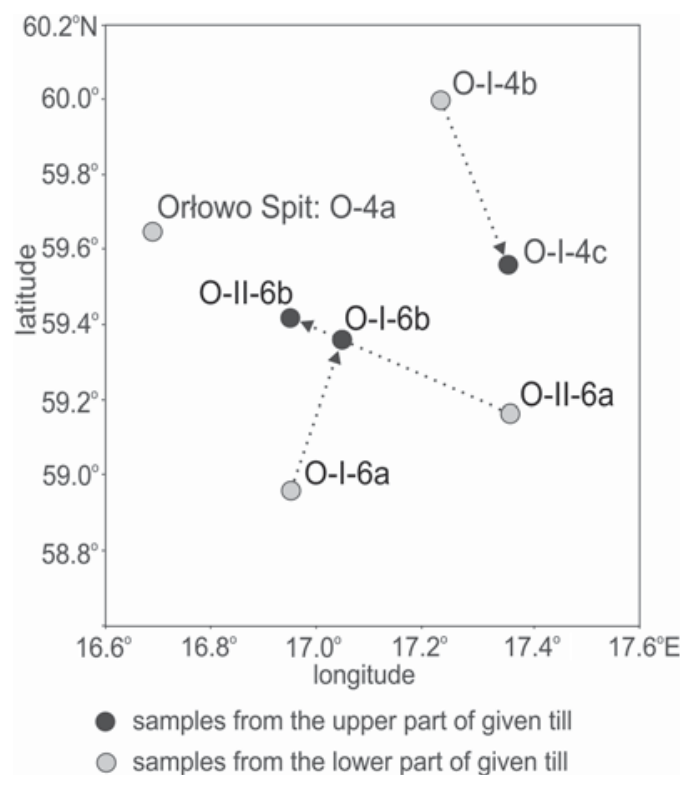

Fig. 5. Theoretical boulder centres (TBC) of samples of the $>20 \mathrm{~mm}$ fraction; location of samples - see Figs. 1C, 2A and 3A; the applied method was originally proposed by Lüttig (1958) and later modified by Smed (1993), Vinx et al. (1997) and Czubla (2001); arrows show the direction of TBC shift.

deformed bodies of the incorporated Miocene sediments (drag folds incised by reverse sub-horizontal faults).

In the southern part of the cliff the till is covered with diamictic-sandy sediments of variable thickness, reaching up to $5 \mathrm{~m}$, while north of Orłowo Horn the cover is virtually missing (Unit O-6; see Fig. 1C, D). At its base, right over the till, locally there is a thin layer of massive and laminated clayey-silt sediments. Above, in the main part of the cover, these deposits are lithologically very diverse and usually deformed. The size of the deformation varies: from slump faults cutting packages of sediments of preserved primary sedimentary structures, to the significant reworking of the original material as a result of mass movements.

\section{Petrographic composition of the 5-10 $\mathrm{mm}$ fraction}

The petrographic composition of the till present in the upper part of Orłowo Cliff was analysed in both research profiles (Figs. 2A and 3A). This issue was better researched in the site located in the southern part of the cliff, because of a clear facies differentiation of the profile and a lack of decalcification of its top part. Despite the inability to correlate the two profiles completely, there is a clear convergence in the petrographic composition of their lower parts. In both sections, in these lower parts there is a predominance of sedimentary over crystalline rocks which increases upwards (coefficient $\mathrm{O} / \mathrm{K}$ grows to approx. 2). The phenomenon responsible for this is largely a significant (approximately twofold) increase in the share of Palaeozoic sandstones with distance from the base. It should also be noted that in this part of the profile the content of Palaeozoic dolomites is stable and relatively high (4-5\%) whereas the 
quantity of such rocks in the lower part is very low. Above a few-centimetres, sandy intercalations in the till occur in the southern part of the cliff (Fig. 3A), which means starting from sample no. 3, the trend described for the lower part is repeated: first the proportion of Palaeozoic sandstones is low, and then in the next sample it is more than doubled. The result is an increase of the coefficient $\mathrm{O} / \mathrm{K}$, which for the samples from the top part also remains quite high. The described trend is much less pronounced in the northern profile (Fig. 2A). It is possible that weathering contributed to this trend weaker than in the topmost part of the profile, but was excluded from petrographic studies due to significant decalcification.

The petrographic diversity of the profile, consistent with previously described changes in facies characteristics, resulted in dividing the studied till into two subunits (see Figs. $2 \mathrm{~A}$ and $3 \mathrm{~A}$ ), on which further analyses were carried out.

\section{Petrographic composition of the $>20 \mathrm{~mm}$ fraction}

Petrographic studies of the $>20 \mathrm{~mm}$ fraction were carried out in two sections - in the southern and northern parts of the cliff (Fig. 1). In each of them, both subunits - upper and lower - were sampled separately (Figs. 2A and 3A). In both Orłowo till profiles, over the entire Late Weichselian, there is a small proportion of local rocks $(0.3 \%$ in the lower subunit, rising to $0.8 \%$ in the upper subunit in the ORL-II section, and respectively $0.5 \%$ to $1.9 \%$ in the ORL-I section). Within Baltic-Fennoscandian material, crystalline rocks make up only about $30 \%$. The quantity of the rocks of this group, increased to over $40 \%$, is recorded in the sample from the upper subunit in the ORL-I section. However, it fairly shows clear traces of weathering which eliminated some calcareous rocks more susceptible to it and, thus, modified the proportions between the different groups of rocks. Only limestones in the non-weathered tills account for more than half of all Nordic erratics, and to this $4.8 \%$ to $6.8 \%$ of dolomites must be added. In all the analysed samples there is a noticeably higher proportion of sandstones than dolomites - from $6.2 \%$ in the lower subunit in the ORL-I section to approximately $10.5 \%$ in the upper subunit in the same section; in the ORL-II section the proportion of sandstones decreases from $10.1 \%$ in the lower subunit to $8.0 \%$ in the upper. The extreme case is the already-mentioned partly weathered till in the top part of the ORL-I section, where the proportion of sandstones is nearly six times higher $(10.5 \%)$ than dolomites $(1.8 \%)$. A significant share of sandstones in this till (apart from the influence of secondary processes on the composition of one sample) indicates material from western Fennoscandia brought by the Late Weichselian ice sheet. This means that eastern and western Fennoscandia were equally involved in debris supply. Similar conclusions can be drawn from indicator erratic analysis (Fig. 4D, F) where Åland rocks dominate in the lower subunit in both sections $(31.6 \%$ in ORL-I and $37.5 \%$ in ORL-II), but with a substantial share of material from Uppland (respectively $21.1 \%$ and $21.9 \%$ ), as well as from Småland and Blekinge (21.1\% and 15.6\%) and Dalarna (15.8\% and $12.5 \%$ ). The upper subunit of the Late Weichselian till is dominated by Uppland rocks (respectively $23.4 \%$ and $29.2 \%$ of erratics identified in the ORL-I and ORL-II sections). Slightly smaller proportions - of about $20 \%$ - were found of Åland and Dalarna rocks, while the Småland and Blekinge indicator erratics amount to 15 to $17 \%$ (Fig. 4E, G). In both sections surprisingly high proportions of Bornholm erratics, amounting to over $4 \%$, were also found. Theoretical boulder centres (TBC) for individual samples vary insignificantly $\left(17.4^{\circ} \mathrm{E}, 59.2^{\circ} \mathrm{N}\right.$ and $17.0^{\circ} \mathrm{E}, 59.0^{\circ} \mathrm{N}$ in the lower subunit and $17.0^{\circ} \mathrm{E}, 59.4^{\circ} \mathrm{N}$ and $17.1^{\circ} \mathrm{E}, 59.4^{\circ} \mathrm{N}$ in the upper one; see Fig. 5).

\section{Till fabric}

In each of the delimited subunits clast fabric measurements were conducted. Sets from the lower parts show quite a range of azimuth. Within one dominant sector there are two azimuth clusters approx. $30-40^{\circ}$ away from each other. Lower isotropy is recorded in the series of the upper subunit. In the ORL-I section most clasts show down-glacier inclination (as in Unit O-4 in this profile, see Fig. 2A), which may be attributed to the fact that the tested till bed is not lying horizontally.

In the sets from the ORL-II section the eigenvector azimuth $\mathrm{V}_{1}$ (its values are consistent with the mean azimuth) indicates an ice advance from the NNW sector, while in the ORL-I section - from the $\mathrm{N}$ with a slight deviation towards NNE. It should be noted, however, that in the latter the striae orientation on a boulder in the base of the till $\left(\sim 347^{\circ}\right)$ indicates the NNW sector, and so it is consistent with the dominant vector in the pebble orientation in both sets in the southern profile.

\section{Interpretation}

The discussed till shows significant thickness variation indicating the diverse depositional effectiveness of the ice sheet, visible over a small space. Following this are noticeable facies differences, when comparing the analysed sections of the cliff. The southern part is dominated by melt-out and decoupling till facies in the form of stratified diamicton with very thin sandy laminae (see e.g. Piotrowski and Tulaczyk, 1999; Piotrowski et al., 2006). The nature of the deformation of the sandy bodies occurring in the middle of the bed (Fig. 5B), and repetition of the situation described in the bottom part (melt-out and decoupling till) indicate a record of the impact of active ice on this part of the profile as well. In the section of the cliff to the north of Orłowo Horn the proportions of melt-out and decoupling till facies in the profile are much smaller. Along with the presence of a fairly well developed deformation zone in the substrate, the described characteristics of the till indicate major temporal-spatial variation in the ice flow dynamics which deposited it. This variation was the result of the hydrogeological conditions at the ice sheet base, largely forced by the hydraulic permeability of the substratum (cf. Alley, 
Table 1. Thermoluminescence dating results.

\begin{tabular}{|l|l|c|c|c|c|c|c|c|}
\hline Lab. no. & \multicolumn{1}{|c|}{ Sediment description } & $\begin{array}{c}\text { Depth } \\
{[\mathrm{m}]}\end{array}$ & $\begin{array}{c}{ }^{226} \mathrm{Ra} \\
{[\mathrm{Bq} / \mathrm{kg}]}\end{array}$ & $\begin{array}{c}{ }^{232} \mathrm{Th} \\
{[\mathrm{Bq} / \mathrm{kg}]}\end{array}$ & $\begin{array}{c}{ }^{40} \mathrm{~K} \\
{[\mathrm{~Bq} / \mathrm{kg}]}\end{array}$ & $\begin{array}{c}\text { Dose rate } \\
{[\mathrm{Gy} / \mathrm{ka}]}\end{array}$ & $\begin{array}{c}\text { Equivalent } \\
\text { dose }[\mathrm{Gy}]\end{array}$ & $\begin{array}{c}\text { TL age } \\
{[\mathrm{ka}]}\end{array}$ \\
\hline UG-6665 & fluvial sand of Unit O-5 (middle part) & 5.7 & $7.2 \pm 0.4$ & $9.3 \pm 0.8$ & $263 \pm 29$ & $1.01 \pm 0.10$ & $59.2 \pm 5.9$ & $58.6 \pm 8.8$ \\
\hline UG-6666 & fluvial sand of Unit O-5 (lower part) & 6.0 & $6.2 \pm 0.4$ & $6.7 \pm 0.6$ & $401 \pm 28$ & $1.35 \pm 0.13$ & $38.9 \pm 4.0$ & $28.8 \pm 4.3$ \\
\hline UG-6667 & fluvial sand of Unit O-5 (top part) & 4.8 & $12.5 \pm 0.9$ & $7.0 \pm 0.6$ & $325 \pm 31$ & $1.25 \pm 0.13$ & $40.2 \pm 4.0$ & $32.2 \pm 4.8$ \\
\hline UG-6668 & glaciofluvial sand of Unit O-7 & 4.5 & $11.2 \pm 1.1$ & $11.2 \pm 0.9$ & $411 \pm 29$ & $1.53 \pm 0.15$ & $12.8 \pm 1.4$ & $8.4 \pm 1.4$ \\
\hline UG-7099* & fluvial sand of Unit O-3 (top part) & 6.5 & $6.6 \pm 0.5$ & $9.6 \pm 0.9$ & $224 \pm 23$ & $0.84 \pm 0.08$ & $99.4 \pm 10.4$ & $118 \pm 23$ \\
\hline UG-7100* & fluvial sand of Unit O-3 (middle part) & 12.0 & $6.9 \pm 0.5$ & $9.4 \pm 0.8$ & $237 \pm 25$ & $0.86 \pm 0.08$ & $100.4 \pm 10.2$ & $117 \pm 22$ \\
\hline UG-7101* & fluvial sand of Unit O-2 (middle part) & 32.0 & $6.9 \pm 0.5$ & $6.8 \pm 0.8$ & $425 \pm 28$ & $1.29 \pm 0.10$ & $321.5 \pm 34.1$ & $249 \pm 48$ \\
\hline UG-6806 & fluvial sand of Unit G-2 (lower part) & 23.2 & $5.84 \pm 0.3$ & $7.23 \pm 0.3$ & $235 \pm 22$ & $0.88 \pm 0.09$ & $120.5 \pm 12.0$ & $137 \pm 20$ \\
\hline UG-6807 & fluvial sand of Unit G-2 (lower part) & 22.9 & $4.99 \pm 0.4$ & $4.92 \pm 0.3$ & $245 \pm 22$ & $0.86 \pm 0.09$ & $123.0 \pm 12.1$ & $143 \pm 22$ \\
\hline UG-6808 & fluvial sand of Unit G-2 (lower part) & 21.2 & $4.14 \pm 0.3$ & $2.85 \pm 0.2$ & $244 \pm 23$ & $0.81 \pm 0.08$ & $>179.0$ & $>221$ \\
\hline UG-7082 & fluvial sand of Unit G-2 (upper part) & 9.8 & $9.9 \pm 0.7$ & $9.2 \pm 0.7$ & $400 \pm 29$ & $2.52 \pm 0.22$ & $308.3 \pm 32.0$ & $122 \pm 18$ \\
\hline UG-7083 & fluvial sand of Unit G-2 (upper part) & 11.0 & $4.5 \pm 0.4$ & $4.1 \pm 0.3$ & $253 \pm 24$ & $1.38 \pm 0.10$ & $168.2 \pm 16.4$ & $122 \pm 17$ \\
\hline UG-7084 & fluvial sand of Unit G-2 (middle part) & 12.0 & $3.9 \pm 0.4$ & $3.1 \pm 0.2$ & $218 \pm 21$ & $0.94 \pm 0.10$ & $115.6 \pm 11.9$ & $123 \pm 18$ \\
\hline UG-7085 & fluvial sand of Unit G-2 (middle part) & 14.5 & $4.2 \pm 0.4$ & $4.1 \pm 0.3$ & $237 \pm 24$ & $1.33 \pm 0.12$ & $168.9 \pm 17.0$ & $127 \pm 19$ \\
\hline UG-7086 & fluvial sand of Unit G-2 (lower part) & 17.5 & $3.8 \pm 0.3$ & $2.4 \pm 0.3$ & $208 \pm 20$ & $1.02 \pm 0.10$ & $176.0 \pm 17.2$ & $173 \pm 25$ \\
\hline UG-7087 & fluvial sand of Unit G-2 (lower part) & 20.0 & $3.9 \pm 0.4$ & $2.5 \pm 0.3$ & $236 \pm 22$ & $1.02 \pm 0.10$ & $190.0 \pm 16.9$ & $187 \pm 28$ \\
\hline
\end{tabular}

* previously published in Sokołowski (2014).

1989; Piotrowski et al., 2006; Salamon, 2014; Woźniak and Czubla, 2016). What is more, the directional properties of the analysed till suggest significant influence of the substratum on the ice flow. On the one hand they suggest that the ice sheet which deposited the Late Weichselian till overrode the area from the NNW. At the same time they show that modifications of ice flow are locally recorded, probably forced by the present relief, showing considerable diversity over a small space.

The summary of circle maps shows large similarity in erratic communities in both analysed subunits (Fig. 4D-G). Analysis of the debris source areas of the ice sheet responsible for the deposition of the till indicates a shift (in relation to Unit O-4) of the maximum exaration zone toward the SW. This is evidenced by the increased percentage of south-Swedish and Bornholm rocks and a simultaneous fall in the share of Åland and of east-Baltic erratics (Fig. 4). Similar conclusions can be drawn from the analysis of the TBC (Fig. 5). Almost all TBC points are located SW of the analogous points for the lower till (Unit O-4). The TBC of the upper subunit of till O-6 in both sections are almost identical and shifted north compared to the same indices for the lower subunit (Fig. 4). A similar TBC location is recorded for the Late Weichselian tills from other sites in eastern Pomerania (Woźniak et al., 2009, Woźniak and Czubla, 2015).

\section{AGE CONTROL}

The age of the sandy units (O-2, O-3, O-5 and G-2) as well as the sands above Unit O-6 till (Fig. 3A) are based on sixteen TL dates (Table 1). The possible age of Unit O-4 till can be explained by the results from the northern part of Orłowo Cliff. Eight dates were obtained from Unit G-2 which directly underlies this till (Fig. 2A) showing a range of ages from $187 \pm 28 \mathrm{ka}$ up to $122 \pm 18 \mathrm{ka}$ (Table 1). This time range covers the entire MIS 6 (Saalian Glaciation), MIS 5e (Eemian Interglacial) and the lowest part of the MIS $5 \mathrm{a}-\mathrm{d}$ (Lower Weichselian). Because of discrepancies in the names of glacial periods older than the Eemian in Poland, we use the marine isotope stages after Railsback et al. (2015). However, the textural features, such quartz grains strongly affected by aeolian processes as well as a composition of heavy minerals with a predominance of garnets, suggest rather severe, periglacial(?) conditions during deposition of Unit G-2 (Sokołowski et al., 2010). In this case it rather excludes the warm, interglacial conditions of the Eemian. Therefore we can assume that the younger dates (122 $\pm 18-127 \pm 19 \mathrm{ka}$; Table 1, samples UG-7082-UG-7085) are more reliable for the age of Unit G-2, pointing at MIS $5 \mathrm{~d}$ (the lowest part of the Lower Weichselian). These dates point to a similar age $(173 \pm 25 \mathrm{ka}, 187 \pm 28 \mathrm{ka}$ and $>221 \mathrm{ka}$; Table 1, samples UG-6808, UG-7086 and UG-7087) from beyond the upper age limit reachable by the TL technique (cf. Liritzis et al., 2013). Moreover, these results suggest that Unit O-4 till was probably deposited not earlier than in MIS 4 (Middle Weichselian). There is a thin layer (up to one metre) of horizontally bedded sands between the O-4 and O-6 tills in some parts of Orłowo Cliff. Unfortunately, this layer is strongly deformed and has secondary carbonate cementation (cf. Ciborowski and Jankowski, 2007), which means that it is useless for chronostratigraphic determination. For this reason we cannot define more precisely the upper time limit for O-4 till deposition.

Seven dates were obtained from the southern part of the Orłowo Cliff section (Fig. 3A). The oldest data from Unit O-2 (249 $\pm 48 \mathrm{ka}$; UG-7101) suggest that it could have been deposited during MIS $8 \mathrm{a}$ and/or MIS 7e (Fig. 6). Two dates from Unit O-3 present similar result $(118 \pm 23 \mathrm{ka}$ and $117 \pm 22$ 


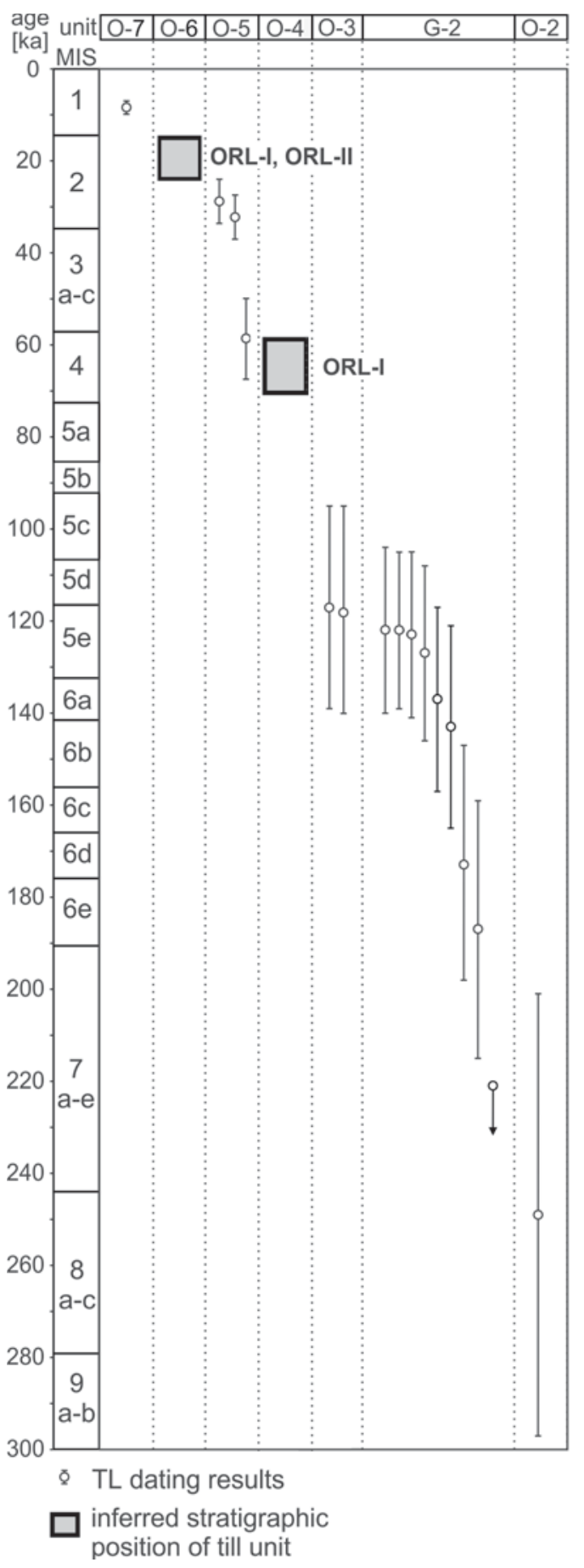

Fig. 6. Summary of the age control of analysed tills; MIS stages after Railsback et al. (2015).

ka; Table 1). We assume that sediments of this unit were deposited probably at the beginning of the Weichselian (MIS 5d; Fig. 6). Fining-upward cycles, prevailing of coarse sand to gravel, as well as trough-cross sedimentary structures suggest sedimentation during flood episodes in a sand-bed, braided river (Sokołowski, 2014). This style of deposition is more frequent under cool to cold, than interglacial climate conditions (Vandenberghe, 2003). Results from Unit O-5 (Figs. 3A and 6) show that this series might has been deposited in MIS 4 (as indicated by the date $58.6 \pm 8.8 \mathrm{ka}$; UG-6665), or more probable - even just before the Late Weichselian (MIS 2), as indicated by the dates $28.8 \pm 4.3 \mathrm{ka}$ (UG-6666) and 32.2 $\pm 4.8 \mathrm{ka}$ (UG-6667). Predominance of gravel trough-cross stratified lithofacies in Unit O-5 suggests rapid aggradation in relatively shallow, gravel-bed braided river. This style of deposition is typical for outwash plains governed by rhythmic glacial ablation (Zieliński, 1992). The date obtained from the topmost sands above O-6 till (8.4 $\pm 1.4 \mathrm{ka}$; UG-6668), shows the early Holocene age. In the light of dates from the southern part of Orłowo Cliff we can assume that the deposition of O-6 till took place during the Late Weichselian.

\section{DISCUSSION}

Results of luminescence dating give a new impulse to determine the stratigraphic position of two till units (O-4 and O-6). Particularly important are amalgamated fluvial series of different ages (O-2, O-3 and O-5 units) without traces of glacial deposition. Similar situation (reduced profile of the Pleistocene) is known from a number of other exposures in the region of Gdańsk Pomerania (cf. Moskalewicz et al., 2016; Woźniak and Czubla, 2016). It is an effect of the predominance of erosion (especially induced by SIS) during the Middle and Late Pleistocene. While the classification of the upper till (Unit O-6) as the Upper Weichselian does not raise wider doubts (Fig. 6), the stratigraphic position of the lower till (Unit O-4) still needs a clearer conclusion. In the light of the dating results, it can be assumed that this till was formed during the Middle Weichselian (MIS 4; Fig. 6). It is supported by a suggested maximum ice extent during the Middle Weichselian in the area south of the Baltic Sea (see Fig. 1A). Even if the 'ageing effect' of the TL-age of sub-till fluvial sediments may occurred (cf. Raukas and Stankowski, 2005; Raukas et al., 2010), the obtained dating results still exclude the older than the Weichselian age of O-4 till. If the upper-lying O-6 till was deposited during the Late Weichselian, the time of deposition of the older, O-4 till should be correlated with an older part of the Weichselian. Such conclusion is supported by the suggested range of deglaciation after the Leszno (= Brandenburg) and Poznań (= Frankfurt) Phases in northern Poland (far to the south of Gdańsk Bay; cf. Wysota et al., 2009; Wysota and Molewski, 2011) and by the presence of a single till of the Upper Weichselian in the surroundings of the Gulf of Gdańsk (Woźniak and Czubla, 2015, 2016; Woźniak et al., 2018). Petrographic analysis results indicate that during the deposition of O-4 till ice masses advanced from the NE part of the Baltic Sea Basin (Fig. 4). Directly in the vicinity of Orłowo Cliff they advanced from the NNW (see till fabric in Fig. 2A). There are no significant differences in the petrographic compositions in the vertical profile, which, together with the results of the lithofacies analysis, leads to the conclusion that it was a continuous subglacial deposition, not interrupted by ice-margin recession episodes in the study area. 
However the till making up the face of cliff at Orłowo Horn, which could be recognised as Unit O-4 as well, reveals a petrographic composition of the $>20 \mathrm{~mm}$ fraction slightly different to that obtained for Unit O-4 in the ORL-I section (see Figs. 4A-C and 5). The high percentage of East-Fennoscandian erratics in O-4 till is very similar to that found in the Late Saalian (MIS 6) tills in central Poland and in the Middle Weichselian till (Świecie Stadial - MIS 4) at the Wiarg site located at the edge of the Lower Vistula Valley, $120 \mathrm{~km}$ south of Orłowo (Czubla, 2011). The same conclusion could be deduced from TBC diagrams, where results for MIS 4 and MIS 6 tills point at eastern Fennoscandia as the main debris source area (cf. Fig. 5 and Czubla, 2001, 2011, 2015). In Pomerania, the situation is less clear, but this may be due to the small number of erratic assemblages researched so far from tills of those ages. Preliminary results obtained at the Babie Doły site, located a little further north of Orłowo, indicate a till with a petrographic composition and position in the Upper Pleistocene profile, very similar to the Unit O-4 in Orłowo Cliff, also exists there (Siniecka, 2014). On the basis of dating results we could suggest that $\mathrm{O}-4$ till should be interpreted as the Middle Weichselian rather than as the Late Saalian.

Differentiation in the petrographic composition in both O-4 till subunits could be interpreted as the effect of a migration of the glaciation centre to the east during the development of an ice sheet (see Ehlers, 1981, 1983; Ehlers and Stephan, 1983). In this case, the lower part of the till at Orłowo Horn could be treated as equivalent to the lower part of O-4 till. High percentage of Dalarna rocks and the resulting western location of TBCs calculated for the lower subunit of O-4 till in Orłowo Horn and in ORL-I profile shows similarity with T5 till at Bełchatów, central Poland, and with B1 lithotype in eastern Poland, correlated with MIS 8 (Czubla, 2001, 2015; Czubla et al., 2018). As presented above, dating results excludes such old age of the O-4 till. The unusual petrographic composition of this till at Orłowo Horn could be explained by the abundant incorporation, by the advancing Middle Weichselian ice sheet, erratic material from older Pleistocene deposits in the surrounded area or from a till contemporary not present in Orłowo Cliff (probably from the stage MIS 8, containing many rocks from middle Sweden). The presence of Miocene sediments within Orłowo Horn could be explained as an effect of subglacial rafting and folding. It is suggested by an increased thickness of O-4 till and strong deformations observed in the northern part of Orłowo Horn (Figs. 1C, 2C, D). This type of deformation may have occurred in conditions of high pore pressure and low permeability of deposits which resulted in decreased cohesion of sediment and its increased susceptibility to deformation (cf. Dowdeswell and Sharp, 1986; Lian et al., 2003). Subglacial erosion can also be the explanation of the lack of O-4 till to the south of Orłowo Horn and its wedging in the northern part of Orłowo Cliff.

The presence of a large amount of deformed Miocene sediments and deformation of O-4 till making up Orłowo Horn under ductile conditions indicates a warm regime at the base of the ice sheet. It can therefore be concluded that during the Late Weichselian SIS advance the tested area was in a transitional zone between slow moving ice masses crossing the area to the west (Kashubian Lake District), and the Vistula palaeo-ice stream in the east, which used the depression of the Bay of Gdańsk (cf. Wysota, 2002; Wysota et al., 2009; Narloch et al., 2013; Woźniak and Czubla, 2015). There is evidence indicating the conditions of sedimentary processes and deformations associated with crossing morphological barriers. These include:

- till thickness variations up to the wedging of the bed (Units O-4 and O-6),

- heterogeneity of the till fabric of the same till (Unit O-6),

- shear systems in the orientation distribution of clasts in till O-6 on both sides of Orłowo Horn,

- clast turnover in till O-4 and in the upper part of till O-6 south of Orłowo Horn.

A significant impact on thermal and hydrogeological conditions at the ice sheet base was also exerted by morphological barriers - plateau elevations. Moreover, an important role was played by a large variation in the permeability of the substrate associated with the occurrence of a mosaic of lithologically diverse deposits, e.g. strongly permeable Pleistocene sands and gravels, and much less permeable sandy-silty Miocene fluvial sediments (cf. Woźniak and Czubla, 2016).

O-6 till has greater diversity compared with the underlying O-4 till. This is particularly evident in the southern part of Orłowo Cliff, where Unit O-6 till reveals a clear dichotomy (Fig. 5). The unit represents the entire upper stadial of the Weichselian Glaciation, and the complexity of its profile is the effect of changes in ice sheet dynamics throughout this period, without the analysed area being freed from ice cover. This means that the southern part of the Bay of Gdańsk was at the hinterland of the main SIS transgression during the Late Weichselian. The obtained results do not allow the delimitation of three subunits, which could be linked to the different phases in the Late Weichselian; rather, we can talk about a dichotomy. In the light of the results of petrographic analyses of the coarsegravel fraction, the lower subunit should be correlated with the Leszno (= Brandenburg) Phase, while the upper with the Poznań-Pomeranian (= Frankfurt-Pomeranian) Phase (cf. Woźniak and Czubla, 2015).

\section{CONCLUSIONS}

The following conclusions can be drawn from the present study.

- Orłowo Cliff contains a clear record of two SIS transgressions in the Upper Pleistocene in separate basal tills (Units O-4 and O-6). In both cases, till sedimentation took place primarily at a time when the research area was in the deep hinterland of the SIS marginal zone.

- Orłowo Cliff shows a distinct reduction in thickness and number of the Pleistocene units. Despite 'the ageing effect' may occurred, obtained dating results suggest the presence of Middle and Late Pleistocene fluvial units 
(deposited most probable in stages MIS 7, MIS 5d and MIS 2/3 respectively).

- TL dating results suggest that O-4 till was deposited during the Middle Weichselian (MIS 4). The lithostratigraphic criterion does not give a clear answer regarding the stratigraphic position of O-4 till. The deposition of O-6 till took place during the Late Weichselian (MIS 2).

- The spatial relationship of TBC indices calculated for tills from Orłowo Horn and in the northern section of Orłowo Cliff could lead to the conclusion that the lower part of Orłowo Horn includes the erratic material derived from an older till in the surrounded area (according to petrographic composition - probably from MIS 8), or from a till contemporary not present in Orłowo Cliff.

- The SIS which deposited the tills studied, varied considerably in the position of the debris source area: Unit O-6 shows a significant shift towards the SW in relation to those areas from which the erratics in Unit O-4 come from. At the same time, changes in the source area during the formation of the younger till bed (O-6) are recorded, which is a reflection of changes in the development of the southern part of the SIS within the entire Late Weichselian.

- The movement of ice during the older SIS advance (Unit O-4) was probably of an ice-stream nature. However, during the next SIS transgression (and deposition of Unit O-6) the area analysed was a boundary zone between the Vistula paleo-ice stream flowing from the north, and ice slowly flowing from the north-west.

\section{Acknowledgments}

We express our thanks to Alicja Bonk, Katarzyna Kozłowska, Marta Kudełka, Patrycja Rój, Justyna Siniecka and Damian Moskalewicz for their help in both fieldwork and samples preparations. We are grateful to Richard Bolt for the linguistic support. The valuable comments of Lucyna Wachecka-Kotkowska and an anonymous reviewer, as well as suggestions of the editor, have greatly helped to improve the manuscript.

\section{REFERENCES}

Alley, R.B., 1989. Water pressure coupling of sliding and bed deformation. II. Velocity-depth profiles. Journal of Glaciology 35, 119-129.

Bogacka, A., Rudowski, S., 2001. Geology of Redłowo Cape (Budowa geologiczna Cypla Redłowskiego). In: Florek, W. (Ed.), Geologia i geomorfologia pobrzeża i południowego Bałtyku, Wydawnictwo Uczelniane PAP Słupsk, 111-117 (in Polish).

Carr, S.J., Rose, J., 2003. Till fabric patterns and significance: particle response to subglacial stress. Quaternary Science Reviews 22, 1415-1426.

Ciborowski, T., Jankowski, M., 2007. Carbonate cementation of sandy sediments on the cliff in Gdynia-Orłowo. Przegląd Geologiczny 55, 140-145 (in Polish with English summary).

Czubla, P., 2001. Fennoscandian Erratics in Quaternary Deposits of Middle Poland and their Value for Stratigraphic Purposes. Acta Geographica Lodziensia 80, 1-174 (in Polish with English summary).

Czubla, P., 2011. The stratigraphic position of a till exposed on the left bank of the Vistula river valley in Wiąg site in the light of indicator erratics analysis (Pozycja stratygraficzna gliny odsłoniętej na lewym brzegu doliny Wisły w Wiągu w świetle analizy eratyków przewodnich). In: Kordowski, J., Lamparski, P., Pochocka-Szwarc, K. (Eds.), XVIII Konferencja Naukowo-Szkoleniowa Stratygrafia Plejstocenu Polski „Rozwój i zanik lądolodu fazy pomorskiej zlodowacenia Wisły na Pomorzu Wschodnim (Kociewie)", Stara Kiszewa 5-9 września 2011, PIG-PIB, Warszawa, 24-25 (in Polish).

Czubla, P., 2015. Fennoscandian erratics in glacial sediments of Poland and their research significance. Wydawnictwo Uniwersytetu Łódzkiego, Łódź, 335 pp. (in Polish with English summary).

Czubla, P., Terpiłowski, S., Orłowska, A., Zieliński, P., Zieliński, T., Pidek, I.A., 2018. Petrographic features of tills as a tool in solving stratigraphical and palaeogeographical problems - a case study from Central-Eastern Poland. Quaternary International. http://dx. doi.org/10.1016/j.quaint.2017.08.028

Dowdeswell, J.A., Sharp, M., 1986. Characterization of pebble fabrics in modern terrestrial glacigenic sediments. Sedimentology 33 , 699-710.

Dreimanis, A., 1962. Quantitative gasometric determination of calcite and dolomite by using Chittick apparatus. Journal of Sedimentary Petrology 32, 520-529.

Ehlers, J., 1981. Problems of the Saalian Stratigraphy in the Hamburg area. Mededelingen Rijks Geologische Dienst 34, 5, 26-29.

Ehlers, J., 1983. Different till types in North Germany and their origin. In: Evenson, E.B., Schlüchter, Ch., Rabassa, J. (Eds.), Tills and related deposits. A.A. Balkema, Rotterdam, 61-80.

Ehlers, J., Stephan, H.J., 1983. Till fabric and ice movement. In: Ehlers, J. (Ed.), Glacial deposits in North-West Europe. A.A. Balkema, Rotterdam, 267-274.

Eyles, N., Eyles, C.H., Miall, A.D., 1983. Lithofacies types and vertical profile models; an alternative approach to the description and environmental interpretation of glacial diamict and diamictite sequences. Sedimentology 30, 393-410.

Fedorowicz, S., Łanczont, M., Bogucki, A., Kusiak, J., Mroczek, P., Adamiec, G., Bluszcz, A., Moska, P., Tracz, M., 2013. Loess-paleosol sequence at Korshiv (Ukraine) - chronology based on complementary and parallel dating (TL, OSL), and litho-pedosedimentary analyses. Quaternary International 296, 117-130.

Fredén, C. (Ed.), 1994. National Atlas of Sweden, Geology. Almqvist \& Wiksell International, Stockholm, $208 \mathrm{pp}$.

Houmark-Nielsen, M., 2010. Extent, age and dynamics of Marine Isotope Stage 3 glaciations in the southwestern Baltic Basin. Boreas 39, 343-359.

Hughes, A.L.C., Gyllencreutz, R., Lohne, Ř.S., Mangerud, J., Svendsen, J.I., 2016. The last Eurasian ice sheets - a chronological database and time-slice reconstruction, DATED-1. Boreas 45, 1-45.

Kaulbarsz, D., 2005. Geology and glaciotectonics of the Orłowo Cliff in Gdynia, northern Poland. Przegląd Geologiczny 53, 572-582 (in Polish with English summary).

Koutaniemi L., Rachocki A.H., 1987. Origin of pradolinas. Zeitschrift für Gletscherkunde und Glazialgeologie 23, 65-76.

Kozarski, S., 1988. Origin of pradolinas: a discussion of mistaken ideas. Zeitschrift für Gletscherkunde und Glazialgeologie 24, 75-92.

Kramarska, R., 2006. Paleogene and Neogene of southern Balic Sea and its coastline (Paleogen i neogen południowego Bałtyku i jego wybrzeża). Ph.D. thesis. Centr. Arch. Geol. Państw. Inst. Geol., Warszawa, 1-139 (in Polish).

Lian, O.B., Hicock, S.R., Dreimanis, A., 2003. Laurentide and Cordilleran fast ice flow: some sedimentological evidence from Wisconsinan subglacial till and its substrate. Boreas 32, 102-113.

Lindner, L., Marks, L., Nita, M., 2013. Climatostratigraphy of interglacials in Poland: Middle and Upper Pleistocene lower boundaries from a Polish perspective. Quaternary International 292, 113-123.

Liritzis, I., Singhvi, A.K., Feathers, J.K., Wagner, G.A., Kardereit, A., 
Zacharias, N., Li, S.-H., 2013. Luminescence dating in archaeology, anthropology and geoarchaeology. An Overview. Springer Briefs in Earth System Sciences. Springer International Publishing, Heidelberg, New York, Dordrecht, London, 70 pp.

Lisicki, S., 2003. Lithotypes and lithostratigraphy of tills of the Pleistocene in the Vistula drainage basin area, Poland. Prace PIG 177, 1-105 (in Polish with English summary).

Lüttig, G., 1958. Methodische Fragen der Geschiebeforschung. Geologisches Jahrbuch 75, 361-417.

Marks, L., 2002. Last Glacial Maximum in Poland. Quaternary Science Reviews 21, 103-110.

Marks, L., 2012. Timing of the Late Vistulian (Weichselian) glacial phases in Poland. Quaternary Science Reviews 44, 81-88.

Miall, A.D., 1978. Lithofacies types and vertical profile models in braided rivers: a summary. In: Miall, A.D. (Ed.), Fluvial sedimentology. Canadian Society of Petroleum Geology Memoir 5, 597-604.

Mojski, J.E., 1979a. Outline of stratigraphy of the Pleistocene and its basement in Gdańsk region (Zarys stratygrafii plejstocenu i budowy jego podłoża w regionie gdańskim). Biuletyn Instytutu Geologicznego, 317, 5-45 (in Polish).

Mojski, J.E., 1979b. Explanation for the detailed geological map of Poland, sheet Gdynia (Objaśnienia do szczegółowej mapy geologicznej Polski arkusz Gdynia). Wydawnictwa Geologiczne, 40 pp. (in Polish).

Mojski, J.E., 2005. Polish territory in the Quaternary. Outline of the morphogenesis (Ziemie polskie w czwartorzędzie. Zarys morfogenezy). Państwowy Instytut Geologiczny, Warszawa, 404 pp. (in Polish).

Moskalewicz, D., Sokołowski, R.J., Fedorowicz, S., 2016. River response to climate and sea level changes during the Late Saalian/ Early Eemian in northern Poland - a case study of meandering river deposits in the Chłapowo cliff section. Geologos 22, 1-14.

Narloch, W., Wysota, W., Piotrowski, J.A., 2013. Sedimentological record of subglacial conditions and ice sheet dynamics of the Vistula Ice Stream (north-central Poland) during the Last Glaciation. Sedimentary Geology 293, 30-44.

Pępek, A., Olszak, I.J., 1995. Quaternary of Redłowo Plateau cliffs (Czwartorzęd klifów Kępy Redłowskiej). In: Florek, W. (Ed.), Geologia i geomorfologia pobrzeża i południowego Bałtyku 2. WSP, Słupsk, 153-158 (in Polish).

Piotrowski, J.A., Larsen, N.K. Menzies, J., Wysota, W., 2006. Formation and subglacial till under transient bed conditions: deposition, deformation, and basal decoupling under Weichselian ice sheet lobe, central Poland. Sedimentology 53, 83-106.

Piotrowski, J.A., Tulaczyk, S., 1999. Subglacial conditions under the last ice sheet in northwest Germany: ice-bed separation and enhanced basal sliding? Quaternary Science Reviews 18, 737-751.

Rachocki, A.H., Koutaniemi, L., 1992. The origin of pradolinas: a re-assesment. A reply to S. Kozarski. Zeitschrift für Gletscherkunde und Glazialgeologie 27/28, 37-50.

Railsback, L.B., Gibbard, P.L., Head, M.J., Voarintsoa, N.R.G., Toucanne, S., 2015. An optimized scheme of lettered marine isotope substages for the last 1.0 million years, and the climatostratigraphic nature of isotope stages and substages. Quaternary Science Reviews $111,94-106$.

Raukas, A., Stankowski, W., 2005. Influence of sedimentological composition on OSL dating of glaciofluvial deposits: examples from Estonia. Geological Quarterly 49, 463-470.

Raukas, A., Stankowski, W., Zelčs, V., Šinkūnas, P., 2010. Chronology of the last deglaciation in the south-eastern Baltic Region on the basis of recent OSL dates. Geochronometria 36, 47-54.

Rudowski, S., Łęczyński, L., 2009. Surveys of the shore and seafloor of the Kępa Redłowska area conducted by the Division of Marine Geology between 1997 and 2007. Oceanological and Hydrobiological Studies 38, Supl. 1, 135-146.
Rzechowski, J., 1971. Granulometric-petrographic properties of tills in the drainage basin of the middle Widawka (Granulometrycznopetrograficzne właściwości glin zwałowych w dorzeczu środkowej Widawki). Biuletyn Instytutu Geologicznego 254, 111-155 (in Polish).

Salamon, T., 2014. Basal till and subglacial conditions at the base of the Upper Odra Lobe (southern Poland) during the Odranian Glaciation. Geological Quarterly 58, 4, 779-794.

Siniecka, J., 2014. Stratigraphic position of the second glacial unit in the vicinity of Gdynia (Pozycja stratygraficzna drugiego poziomu glacjalnego w okolicach Gdyni). MSc thesis. University of Gdańsk, Gdańsk, 60 pp. (in Polish).

Smed, P., 1993. Indicator studies: a critical review and a new data-presentation method. Bulletin of the Geological Society of Denmark $40,3-4,332-344$.

Smed, P., 2002. Steine aus dem Norden: Geschiebe als Zeugen der Eiszeit in Norddeutschland. Gebrüder Borntraeger, Berlin-Stuttgart, $194 \mathrm{pp}$.

Sokołowski, R., 2013. Geology of Pleistocene sediments in the northern and southern parts of the Orłowo Cliff (Budowa geologiczna osadów plejstocenu w północnej i południowej części klifu orłowskiego). In: Procesy geologiczne w strefie brzegowej morza. Instytut Oceanografii Uniwersytetu Gdańskiego, Gdynia, 68-69 (in Polish).

Sokołowski, R., 2014. Geology and sedymentologic analysis of sediments of the Orłowo Cliff (Budowa geologiczna i analiza sedymentologiczna osadów klifu orłowskiego). In: Sokołowski, R.J. (Ed.), Ewolucja środowisk sedymentacyjnych regionu Pobrzeża Kaszubskiego. Uniwersytet Gdański, Gdynia, 103-114 (in Polish).

Sokołowski, R.J., Fedorowicz, S., Bonk, A., 2010. New look at the age and genesis of sediments and deformation structures in Orłowo Cliff, northern Poland (Nowe spojrzenie na wiek i genezę osadów i struktur deformacyjnych odsłaniających się w klifie orłowskim w Gdyni, północna Polska). In: Marks, L., Pochocka-Szwarc, K. (Eds.), XVII konferencja „Stratygrafia plejstocenu Polski” - Dynamika zaniku lądolodu podczas fazy pomorskiej w NE części Mazur, Jeziorowskie 6-10.09.2010. Polish Geological Institute, Warszawa, 148-149 (in Polish).

Šliaupa, S., Hoth, P., 2011. Geological Evolution and Resources of the Baltic Sea Area from the Precambrian to the Quaternary. In: Harff, J., Björck, S., Hoth, P. (Eds.), The Baltic Sea Basin, Central and Eastern European Development Studies, Springer Verlag, Berlin Heidelberg, 13-51.

Trembaczowski, J,. 1961. Contribution to methodology of granulometricpetrographic examination of morainic sediments. Annales Universitatis Maria Curie-Skłodowska, Sectio B 16, 3, 63-94 (in Polish with English summary).

Vandenberghe, J., 2003. Climate forcing of fluvial system development: an evolution of ideas. Quaternary Science Reviews 22, 2053-2060.

Vinx, R., Grube, A., Grube, F., 1997. Vergleichende Lithologie, Geschiebeführung und Geochemie eines Prä-Elster-I-Tills von Lieth bei Elmshorn. Leipziger Geowissenschaften 5, 83-103.

Wintle, A.G., Prószyńska, H., 1983. TL Dating of loess in Germany and Poland. PACT 9, 547-554.

Woźniak, P.P., Czubla, P., 2014. New look at glacial deposits at Gdynia Orłowo (Nowe spojrzenie na gliny lodowcowe w Gdyni Orłowie). In: Sokołowski, R.J. (Ed.), Ewolucja środowisk sedymentacyjnych regionu Pobrzeża Kaszubskiego. Uniwersytet Gdański, Gdynia, 115-122 (in Polish).

Woźniak, P.P., Czubla, P., 2015. The Late Weichselian glacial record in northern Poland - a new look at debris transport routes by the Fennoscandian Ice Sheet. Quaternary International 386, 3-17.

Woźniak, P.P., Czubla, P., 2016. Unravelling the complex nature of the Upper Weichselian till section at Gdynia Babie Doły, northern Poland. Geologos 22, 1, 15-32.

Woźniak, P.P., Czubla, P., Domachowski, W., Świrydo, M., 2018. Directional properties of glacial relief and sediments as an effect of 
multi-stage evolution: case study of the Tczew Hump, northern Poland. Quaternary International, doi 10.1016/j.quaint.2017.09.033.

Woźniak, P.P., Czubla, P., Wysiecka, G., Drapella, M., 2009. Petrographic composition and directional properties of tills on the NW surroundings of Gdańsk Bay, Northern Poland. Geologija 51, 3-4, 59-67.

Wysota, W., 2002. Stratigraphy and sedimentary environments of the Weichselian glaciation in the southern part of the lower Vistula region. Wydawnictwo UMK, Torun, 144 pp. (in Polish with English summary).

Wysota, W., Molewski, P., Sokołowski, R.J., 2009. Record of the Vistula ice lobe advances in the Late Weichselian glacial sequence in north-central Poland. Quaternary International 207, 26-41.
Wysota, W., Molewski, P., 2011. Chronology and extents of ice sheet advances in the Vistula lobe area during the Main Stage of the Last Glaciation. Przegląd Geologiczny 59, 214-225 (in Polish with English summary).

Zaleszkiewicz, L., Masłowska, M., Olszak, I.J., Koszka-Maroń, D., Michałowska, M., 2000. Cliff in Gdynia-Orłowo (Klif w GdyniOrłowie). In: Uścinowicz, Sz., Zachowicz, J. (Eds.), Stratygrafia czwartorzędu i zanik lądolodu na Pojezierzu Kaszubskim: VII Konferencja „Stratygrafia plejstocenu w Polsce”, Państwowy Instytut Geologiczny, 124-127 (in Polish).

Zieliński, T., 1992. Proglacial valley facies of the Silesian Upland genetic factors and their sedimentological effects. Geologia Sudetica $26,83-118$. 